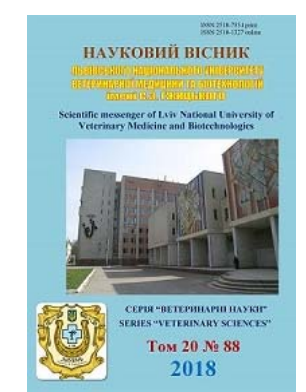

\author{
Науковий вісник Яьвівського національного університету \\ ветеринарної медицини та біотехнологій імені С.З. Гжицького
}

\author{
Scientific Messenger of Lviv National University \\ of Veterinary Medicine and Biotechnologies
}

UDC 619:619.661

\title{
Influence of cadmium loading on morphological parameters of blood of the Laying Hens
}

\author{
A.Y. Ostapyuk, B.V. Gutyj \\ Stepan Gzhytskyi National University of Veterinary Medicine and Biotechnologies Lviv, Ukraine
}

Article info

Received 08.08.2018

Received in revised form 03.09 .2018

Accepted 04.09.2018

Stepan Gzhytskyi National University of Veterinary Medicine and Biotechnologies Lviv,

Pekarska Str., 50, Lviv, 79010

Ukraine.

Tel.: +38-068-136-20-54

E-mail:bvh@ukr.net
Ostapyuk, A.Y., \& Gutyj, B.V. (2018). Influence of cadmium loading on morphological parameters of blood of the Laying Hens. Scientific Messenger of Lviv National University of Veterinary Medicine and Biotechnologies, 20(88), 48-52. doi: 10.32718/nvlvet8808

The article presents the results of studies on the influence of cadmium sulfate in different doses on the organism of poultry. The purpose of the work was to investigate the effect of cadmium sulfate in doses of 2 and $4 \mathrm{mg} / \mathrm{kg}$ body weight on the morphological parameters of blood of the Laying Hens. By the evaluation of the morphological analysis of the quantitative and qualitative composition of blood, it is possible to deem objectively about the functional state of the hematopoietic system of the body of the bird for cadmium loading. For research were formed three experimental groups: control group and two research groups. The control group chickens were in the usual diet, they were fed with combined feed and drank water without cadmium sulfate. To the drinking water of chickens of experimental groups added cadmium sulfate for 30 days: the first group $-2 \mathrm{mg} / \mathrm{kg}$ body weight of cadmium sulfate, the second group $-4 \mathrm{mg} / \mathrm{kg}$ body weight of cadmium sulfate. The conditions and microclimate parameters in the room for all keeping chickens groups were similar. Blood from Laying Hens was taken from the subclavian (axillary) vein in the following periods: before taking the drugs and cadmium sulfate, on the first, seventh, fourteenth, twenty-first and thirtieth day of the experiment. Hematologic studies give an opportunity to study in detail the influence of cadmium on the body of chickens, on the basis of which a more correct development of the scheme of treatment and prevention of cadmium toxicity in poultry is possible. Drinking cadmium sulfate in doses of 2 and $4 \mathrm{mg} / \mathrm{kg}$ of body weight contributed to a decrease in the number of erythrocytes to $2.69 \pm 0.13$ and $2.36 \pm 0.14 \mathrm{~T} / \mathrm{l}$, a hemoglobin level of $86.61 \pm 1.11$ and $72.17 \pm 0.73 \mathrm{~g} / \mathrm{l}$ and an increase in the number of leukocytes to $34.9 \pm$ 0.60 and $35.8 \pm 0.66 \mathrm{~g} / \mathrm{l}$. Probable changes in morphological parameters are observed on the 21 st day of the experiment in the second experimental group of Laying Hens, which were released cadmium sulfate at a dose of $4 \mathrm{mg} / \mathrm{kg}$ body weight. The hematocrit value represents the ratio between the formed elements and the blood plasma. After chickens drinking with cadmium sulfate at doses of 2 and $4 \mathrm{mg} / \mathrm{kg}$ of body weight, the hematocrit value gradually decreased. The hematocrit value was low in the second experimental group on day 21 of the experiment, where, respectively, it was $34.11 \pm 0.63 \%$.

Key words: toxicology, cadmium sulfate, poultry, morphological parameters, blood.

\section{Вплив кадмієвого навантаження на морфологічні показники крові птиці}

\author{
А.Ю. Остап’юк, Б.В. Гутий
}

Львівський національний університет ветеринарної медицини та біотехнологій імені С.3. Гжицького, м. Львів, Україна

У статті наведено результати досліджень впливу сульфату кадмію у різних дозах на організм птиці. Метою роботи було з'ясували вплив кадмію сульфату у дозах 2 i 4 мг/кг маси тіла на морфологічні показники крові курей-несучок. За оцінкою морфологічного аналізу кількісного та якісного складу крові можна досить об'єктивно судити про функціональний стан кровотворної системи організму птиці за кадмієвого навантаження. Для досліджень було сформовано три групи птиці: контрольну і дві дослідні. Кури контрольної групи знаходилися на звичайному рачіоні, їм згодовували комбікорм та випоювали воду без внесення сульфату кадмію. До питної води курей дослідних груп протягом 30 діб додавали сульфат кадмію в дозах: перша група - 2 мг/кг, друга група - 4 мг/кг маси тіла. Умови утримання курей та параметри мікроклімату в приміщенні для всіх груп птиці були аналогічними. Кров у курей-несучок відбирали із підкрильцевої вени у періоди: до початку задавання препарату та на периу, сьому, чотирнадияту, двадиять першу та тридияту доби досліду. Гематологічні дослідження дають можливість детальніше вивчати вплив 
кадмію на організм курей, на підставі чого можлива правильніша розробка конкретної схеми лікування та профілактики кадмієвого токсикозу у птиці. Випоювання курям-несучкам сульфату кадмію у дозах 2 i 4 мг/кг маси тіла, сприяло зниженню кількості

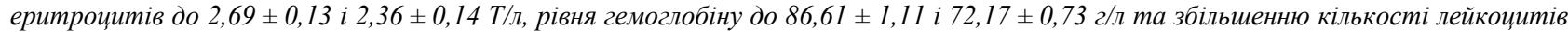

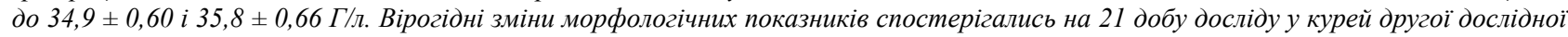
групи, яким випоювали сульфат кадмію у дозі 4 мг/кг маси тіла. Гематокритна величина відображає співвідношення між форменими елементами і плазмою крові. Після випоювання курям-несучкам сульфату кадмію у дозах 2 i 4 мг/кг маси тіла величина гематокриту поступово знижувалася. Найнижчою вона була у другої дослідної групи на 21 добу досліду, де відповідно вона становила $34,11 \pm 0,63 \%$.

Ключові слова: токсикологія, сульфат кадмію, птиця, морфологічні показники, кров.

\section{Вступ}

Проблема забруднення навколишнього середовища Кадмієм, що $є$ одним із наслідків інтенсифікації промислового й аграрного виробництва, нині набула особливої актуальності (Uetani et al., 2005; Nazaruk et al., 2015; Sachko et al., 2016). Упродовж останніх десятиріч зростання вмісту цього металу в грунтах України та інших країн супроводжується нагромадженням $\mathrm{Cd}^{2+}$ у сільськогосподарській продукції та кормах, збільшенням загрози здоров'ю людини і тварин (Hutyi, 2013; Gutyj et al., 2015; Hradovych et al., 2016; Grushanska, 2017).

Токсичний вплив кадмію проявляється щодо низки тканин і органів (нирки, печінка, легені, статеві залози), систем (видільна, серцево - судинна, кровотворна) (Fregoneze et al., 1997; Rodríguez et al., 2001; Lu et al., 2005; Liu et al., 2008; Al-Azemi et al., 2010). Кадмій характеризується довгим півперіодом існування в організмі людини і тварини, взаємодією 3 двовалентними металами, як на рівні абсорбції, так на рівні метаболізму в тканинах і органах (Antonio et al., 1998; Pavan Kumar and Prasad, 2004; El-Shahat et al., 2009).

Кадмій та його сполуки відносяться до імунотоксикантів, які викликають порушення у функціонуванні імунної системи організму, знижують резистентність до інфекцій, сприяють формуванню алергічних, аутоімунних та онкологічних патологій (Ali et al., 1986; Salvatori et al., 2004; El-Refaiy and Eissa, 2012; Peng et al., 2015; Gutyj, 2015).

У зв'язку з цим особливості впливу Кадмію на організм людини і тварин - це предмет детального вивчення, особливо впродовж останнього десятиріччя.

Мета роботи - дослідити вплив сульфату кадмію у дозах 2 i 4 мг/кг маси тіла на морфологічні показники крові курей-несучок.

\section{Матеріал і методи досліджень}

Для досліду було відібрано 24 курки-несучки кросу Хайсекс білий, віком 78 тижнів, з яких сформували три групи: контрольну і дві дослідні. Групи формувалися за принципом аналогів (вік і жива маса). Курей різних груп мітили стійкими органічними барвниками. Кури контрольної групи знаходилися на звичайному раціоні, їм згодовували комбікорм та випоювали воду без внесення сульфату кадмію. До питної води курей дослідних груп протягом 30 діб додавали кадмію сульфат в дозах: перша група - 2 мг/кг, друга група -4 мг/кг маси тіла.
Умови утримання та параметри мікроклімату в приміщенні для всіх груп птиці були аналогічними. Впродовж досліду обліковували кількість спожитого корму і води.

Усі експериментальні втручання та забій тварин проводили 3 дотриманням вимог “Свропейської конвенції про захист хребетних тварин, яких використовують для експериментальних та наукових цілей” (Страсбург, 1985) та ухвали Першого національного конгресу з біоетики (Київ, 2001).

Кров у курей-несучок відбирали із підкрильцевої вени у періоди: до початку задавання кадмію сульфату та на першу, сьому, чотирнадцяту, двадцять першу та тридцяту доби досліду.

У стабілізованій гепарином крові визначали кількість еритроцитів - фотонефелометрично за методикою Є.С. Гаврилець і співавт. (1966); лейкоцитів - за допомогою сітки Горяєва у лічильній камері (В.Е. Чумаченко, 1991); концентрацію гемоглобіну гемоглобінціанідним методом за Г.В. Дервіз і А.Г. Воробйовим (1959); величину гематокриту - за методом І.П. Кондрахіна (1983) (Vlizlo, 2012).

Аналіз результатів досліджень проводили за допомогою пакету програм Statistica 6.0. Вірогідність різниць оцінювали за t-критерієм Стьюдента. Результати середніх значень вважали статистично вірогідними при * - $\mathrm{P}<0,05, * *-\mathrm{P}<0,01, * * *-\mathrm{P}<0,001$ (ANOVA).

\section{Результати та їх обговорення}

Склад крові - відносно сталий показник, який водночас $є$ однією з лабільних систем організму курейнесучок. Фізіологічні процеси, які відбуваються в організмі, значною мірою позначаються на якісному складі крові (Gutyj et al., 2015; Gutyj et al., 2016). Гематологічні дослідження дають можливість детальніше вивчати вплив кадмію на організм курей, на підставі чого можлива більш конкретна розробка схеми лікування та профілактики кадмієвого токсикозу у птиці.

Згідно даних таблиці 1, кількість еритроцитів у крові курей до випоювання їм досліджуваного препарату, як дослідних так і контрольної груп, знаходилася у межах фізіологічних величин, а саме: у межах $3,15 \pm 0,10-3,22 \pm 0,10$ Т/л. Після випоювання їм 3 водою сульфату кадмію у дозі 2 мг/кг маси тіла, кількість еритроцитів на 7 добу досліду зросла до $3,29 \pm 0,16$ Т/л, тоді як у контрольної групи даний показник становив $3,21 \pm 0,13 \mathrm{~T} /$ л. У курей другої дослідної групи кількість еритроцитів у вказаний період досліду була найнижчою. 
У подальшому в крові курей дослідних груп відзначали зменшення числа еритроцитів, які на 14-у добу досліду знизилися на 6,2\% у крові птиці першої дослідної групи та на 11,7\% - у крові дослідної групи Д2. На 21- і 30-у доби досліду кількість еритроцитів продовжувала знижуватися i, відповідно, у першій дослідній групі знизилася до 2,69 $\pm 0,13$ Т/л, а у другій - до 2,36 $\pm 0,14$ Т/л, тоді як у курей контрольної групи даний показник коливався у межах $3,23 \pm$ 0,13 Т/л. На 30-у добу досліду кількість еритроцитів у крові курей дослідних груп порівняно з попередньою добою, дещо зросла, однак порівняно з показником курей контрольної групи залишалася на низькому рівні.

Аналогічні зміни спостерігаємо і при дослідженні рівня гемоглобіну. Відомо, що гемоглобін це дихальний пігмент крові, який виконує, в основному, роль переносника молекулярного оксигену від органів дихання до тканин (Khariv et al., 2016). Як видно 3 даних таблиці рівень гемоглобіну у крові курей контрольної групи впродовж усього досліду коливався в межах 97,67 $\pm 0,76$ г/л.

\section{Таблиця 1}

Морфологічні показники крові курей-несучок за кадмієвого навантаження $(\mathrm{M} \pm \mathrm{m}, \mathrm{n}=8)$

\begin{tabular}{|c|c|c|c|c|c|}
\hline \multirow{2}{*}{$\begin{array}{c}\text { Дослідні } \\
\text { групи } \\
\end{array}$} & \multirow{2}{*}{ До випоювання } & \multicolumn{4}{|c|}{ Доби дослідження } \\
\hline & & 7 & 14 & 21 & 30 \\
\hline \multicolumn{6}{|c|}{ Еритроцити, Т/л } \\
\hline $\mathrm{K}$ & $3,19 \pm 0,12$ & $3,21 \pm 0,13$ & $3,25 \pm 0,12$ & $3,23 \pm 0,13$ & $3,20 \pm 0,12$ \\
\hline Д1 & $3,22 \pm 0,10$ & $3,29 \pm 0,16$ & $3,05 \pm 0,11$ & $2,69 \pm 0,13 * *$ & $2,85 \pm 0,15 *$ \\
\hline Д2 & $3,15 \pm 0,10$ & $3,07 \pm 0,15$ & $2,87 \pm 0,14$ & $2,36 \pm 0,14 * * *$ & $2,49 \pm 0,16 * *$ \\
\hline \multicolumn{6}{|c|}{ Гемоглобін, г/л } \\
\hline $\mathrm{K}$ & $97,67 \pm 0,76$ & $98,46 \pm 0,63$ & $99,11 \pm 0,70$ & $98,55 \pm 0,77$ & $97,67 \pm 0,76$ \\
\hline Д1 & $99,15 \pm 0,66$ & $102,43 \pm 1,12 *$ & $93,23 \pm 1,32 * *$ & $86,61 \pm 1,11 * * *$ & $90,72 \pm 1,21 * *$ \\
\hline Д2 & $98,58 \pm 0,73$ & $87,32 \pm 1,10 * *$ & $81,22 \pm 1,20 * * *$ & $72,17 \pm 0,73 * * *$ & $83,56 \pm 0,93 * *$ \\
\hline \multicolumn{6}{|c|}{ Гематокрит, \% } \\
\hline $\bar{K}$ & $39,18 \pm 0,70$ & $39,63 \pm 0,73$ & $39,44 \pm 0,68$ & $39,71 \pm 0,75$ & $39,60 \pm 0,73$ \\
\hline Д1 & $39,54 \pm 0,67$ & $38,23 \pm 0,67$ & $37,84 \pm 0,90$ & $36,10 \pm 0,74^{*}$ & $37,44 \pm 0,85^{*}$ \\
\hline Д2 & $39,43 \pm 0,75$ & $37,56 \pm 0,81$ & $36,71 \pm 0,80^{*}$ & $34,11 \pm 0,63^{* *}$ & $35,23 \pm 0,90 *$ \\
\hline \multicolumn{6}{|c|}{ Лейкоцити, Г/л } \\
\hline K & $31,7 \pm 0,75$ & $31,5 \pm 0,58$ & $31,9 \pm 0,55$ & $31,8 \pm 0,55$ & $31,7 \pm 0,65$ \\
\hline Д1 & $31,9 \pm 0,70$ & $33,9 \pm 0,55^{*}$ & $34,2 \pm 0,70^{*}$ & $34,9 \pm 0,60^{*}$ & $33,8 \pm 0,70^{*}$ \\
\hline Д2 & $31,8 \pm 0,70$ & $34,1 \pm 0,70^{*}$ & $34,7 \pm 0,65^{*}$ & $35,8 \pm 0,66^{* *}$ & $34,1 \pm 0,70^{*}$ \\
\hline
\end{tabular}

При випоюванні з водою сульфату кадмію у дозі 2 мг/кг маси тіла встановлено незначне підвищення рівня гемоглобіну у крові даної дослідної групи, що можливо пов'язано із захисно-пристосувальною реакцією організму на надходження токсиканту. На 14- і 21-у доби досліду у крові курей першої дослідної групи рівень гемоглобіну поступово знижувався до $86,61 \pm 1,11$ г/л, тоді як у контролі даний показник становив 98,55 $\pm 0,77$ г/л, що на $12 \%$ був нижчим за показники контролю.

При випоюванні птиці з водою сульфату кадмію у дозі 4 мг/кг маси тіла, встановлено поступове зниження рівня гемоглобіну вже починаючи з 7-ої доби досліду. У наступні періоди досліджень рівень гемоглобіну продовжував знижуватися, де на 14-у добу знизився на $18 \%$, на $21-$ у добу - на 26,8\%, відносно показників контрольної групи курей.

Гематокритна величина відображає співвідношення між форменими елементами і плазмою крові. Після випоювання курям-несучкам сульфату кадмію у дозах 2-4 мг/кг маси тіла величина гематокриту поступово знижувалася (табл. 1). Найнижчим цей показник був у курчат другої дослідної групи на 21-у добу досліду, де відповідно він становив $34,11 \pm 0,63 \%$.

Результати досліджень на курях-несучках (табл. 1) показали, що після випоювання їм 3 водою кадмію сульфату у дозі 2 мг/кг маси тіла, кількість лейкоцитів у їх крові поступово зростала протягом усього досліду: на 7-у добу зросла на 7,6\%, на 14-у добу - на 7,2\%, на 21-у добу - на 9,7\%, на 30 добу - на 6,6\%. При випоюванні з водою кадмію сульфату у більш високій дозі (4 мг/кг маси тіла) також встановлено збільшення числа лейкоцитів у крові птиці другої дослідної групи. Найбільшою кількість лейкоцитів у крові даної дослідної групи була на 14-у і 21-у доби досліду, де порівняно 3 показниками контрольної групи курей вона збільшилася на 8,8 і 12,6\%, відповідно. Лейкоцитоз, очевидно, зумовлений розвитком запальних процесів у травному каналі за впливу токсичної дії кадмію, у результаті чого кількість лейкоцитів у крові курей зростає.

\section{Висновки}

Випоювання курям-несучкам сульфату кадмію у дозах 2 і 4 мг/кг маси тіла, сприяло зниженню кількості еритроцитів, рівня гемоглобіну та збільшенню числа лейкоцитів. Вірогідні зміни морфологічних показників спостерігаємо на 21-у добу досліду у курей другої дослідної групи, яким випоювали сульфат кадмію у дозі 4 мг/кг маси тіла.

\section{References}

Uetani, M., Kobayashi, E., Suwazono, Y., Okubo, Y., Honda, R., Kido, T., \& Nogawa, K. (2005). Selenium, Cadmium, Zinc, Copper, and Iron Concentrations in Heart and Aorta of Patients Exposed to Environmental 
Cadmium. Bulletin of Environmental Contamination and Toxicology, 75(2), 246-250. doi: 10.1007/s00128005-0744-6.

Nazaruk, N., Gutyj, B.V., \& Hufriy, D. (2015). Influence of metifen and vitamix se on the activity of aminotransferases of bulls blood serum at cadmium nitrate loading. Scientific Messenger of LNU of Veterinary Medicine and Biotechnologies, 17(1), 121126. Retrieved from https://nvlvet.com.ua/index.php/ journal/article/view/231.

Sachko, R.G., Lesyk, Ja.V., Luchka, I.V., \& Nevostruyeva, I.V. (2016). Contents of heavy metals in food, organism and animal products in the Zacarpathian biogeochemical province. Scientific Messenger LNUVMBT named after S.Z. Gzhytskyj, 18, 3(71), 87-90. doi: 10.15421/nvlvet7120.

Hutyi, B.V. (2013). Vplyv khlorydu kadmiiu u toksychnykh dozakh na hlutationovu systemu antyoksydantnoho zakhystu orhanizmu bychkiv. Veterynarna biotekhnolohiia, 22, 112-116. Rezhym dostupu: http://nbuv.gov.ua/UJRN/vbtb_2013_22_23 (in Ukrainian).

Hutyi, B.V. (2013). Vplyv meveselu ta E-selenu na riven pokaznykiv ne fermentnoi systemy antyoksydantnoho zakhystu orhanizmu buhaitsiv pry kadmiievomu navantazhenni. Veterynarna medytsyna, 97, 419-421. Rezhym dostupu: http://nbuv.gov.ua/UJRN/ vetmed 2013 97172 (in Ukrainian).

Hutyi, B.V. (2013). Vplyv khlorydu kadmiiu u riznykh dozakh na aktyvnist aminotransferaz syrovatky krovi buhaitsiv. Naukovyi visnyk Lvivskoho natsionalnoho universytetu veterynarnoi medytsyny ta biotekhnolohii im. Gzhytskoho, 15, 1(1), 49-52. Rezhym dostupu: http://nbuv.gov.ua/UJRN/nvlnu $2013 \quad 15$ 1(1) 11 (in Ukrainian).

Hutyi, B.V. (2013). Riven pokaznykiv nefermentnoi systemy antyoksydantnoho zakhystu orhanizmu bychkiv za umov kadmiievoho navantazhennia. Naukovyi visnyk Lvivskoho natsionalnoho universytetu veterynarnoi medytsyny ta biotekhnolohii im. Gzhytskoho, 15, 1(4), 40-45. Rezhym dostupu: http://nbuv.gov.ua/UJRN/nvlnu $2013 \quad 15$ 1(4) 10 (in Ukrainian).

Hutyi, B.V. (2013). Vplyv meveselu na vmist vitaminiv A i E u krovi bychkiv za umov kadmiievoi intoksykatsii. Naukovyi visnyk Lvivskoho natsionalnoho universytetu veterynarnoi medytsyny ta biotekhnolohii im. Gzhytskoho, 15, 3(1), 78-82. Rezhym dostupu: http://nbuv.gov.ua/UJRN/nvlnu $2013 \quad 15 \quad 3(1) \quad 18$ (in Ukrainian).

Hutyi, B.V. (2013). Vplyv E-selenu na vmist vitaminiv A i E u krovi bychkiv za umov kadmiievoi intoksykatsii. Naukovyi visnyk Lvivskoho natsionalnoho universytetu veterynarnoi medytsyny ta biotekhnolohii im. Gzhytskoho, 15, 3(3), 311-314. Rezhym dostupu: http://nbuv.gov.ua/UJRN/nvlnu_2013_15_3(3)_55 (in Ukrainian).

Hutyi, B.V. (2013). Vmist vitaminiv A i E u krovi bychkiv za umov kadmiievoi intoksykatsii. Visnyk Sumskoho natsionalnoho ahrarnoho universytetu. Seriia: Veterynarna medytsyna, 2, 31-33. Rezhym dostupu:
http://nbuv.gov.ua/UJRN/Vsna vet 2013210

(in Ukrainian).

Hutyi, B.V. (2013). Vplyv Meveselu na pokaznyky neenzymnoi systemy antyoksydantnoho zakhystu orhanizmu buhaitsiv za umov kadmiievoho navantazhennia. Biolohiia tvaryn, 15(3), 16-21. Rezhym dostupu: http://nbuv.gov.ua/UJRN/bitv 2013 1534 (in Ukrainian).

Hutyi, B.V. (2013). Vplyv E-selenu na aktyvnist hlutationovoi systemy antyoksydantnoho zakhystu orhanizmu buhaitsiv pry kadmiievomu navantazhenni. Visnyk Sumskoho natsionalnoho ahrarnoho universytetu. Seriia: Veterynarna medytsyna. 9, 70-73. Rezhym dostupu: http://nbuv.gov.ua/UJRN/Vsna_vet_2013 922 (in Ukrainian).

Gutyj, B.V., Gufrij, D., Binkevych, V., Binkevych, O., Kurlyak, I., \& Sobolta, A. (2015). Influence of Mevesel \& E-selenium on level of intermediate and final products of lipid peroxidation in bulls' blood after cadmium loading. Scientific Messenger of LNU of Veterinary Medicine and Biotechnologies, 17(1), 190-194. Retrieved from https://nvlvet.com.ua/ index.php/journal/article/view/292.

Hradovych, N., Paranyak, R., \& Zabytivskyi, Y. (2016). Influence of zeolites on lead and cadmium content in separate links of trophic chain in hydroecosystems. Scientific Messenger of LNU of Veterinary Medicine and Biotechnologies, 18, 2(67), 61-65. doi: $10.15421 /$ nvlvet6714.

Grushanska, N. (2017). The content of heavy metals in the cow hair of the northern-eastern biogeochemical zone. Scientific Messenger of LNU of Veterinary Medicine and Biotechnologies, 19(73), 154-158. doi: $10.15421 /$ nvlvet7332.

Fregoneze, J.B., Marinho, C.A., Soares, T., Castro, L., Sarmento, C., Cunha, M., Gonzalez, V., Oliveira, P., Nascimento, T., Luz, C.P., Santana, Jr. P., DeOliveira, I.R., \& e-Castro-e-Silva, E. (1997). Lead $(\mathrm{Pb} 2+)$ and cadmium $(\mathrm{Cd} 2+)$ inhibit the dipsogenic action of central beta-adrenergic stimulation by isoproterenol. Brazilian Journal of Medical and Biological Research, 30(3), 419-423. doi: 10.1590/S0100-879X1997000300018.

Rodríguez, E.M., Bigi, R., Medesani, D.A., Stella, V.S., Greco, L.S.L., Moreno, P.A.R., Monserrat, J.M., Pellerano, G.N., \& Ansaldo, M. (2001). Acute and chronic effects of cadmium on blood homeostasis of an estuarine crab, Chasmagnathus granulata, and the modifying effect of salinity. Brazilian Journal of Medical and Biological Research. 34(4), 509-518. https:/www.ncbi.nlm.nih.gov/pubmed/11285463.

Lu, J., Jin, T., Nordberg, G., \& Nordberg, M. (2005). Metallothionein gene expression in peripheral lymphocytes and renal dysfunction in a population environmentally exposed to cadmium. Toxicol Appl Pharmacol 206(2), 150-156. doi: 10.1016/j.taap.2004.12.015.

Liu, J., Qian, S.Y., Guo, Q., Jiang, J., Waalkes, M.P., Mason, R.P., \& Kadiiska, M.B. (2008). Cadmium generates reactive oxygen- and carbon-centered radicalspecies in rats: Insights from in vivo spintrappingstudies. Free Radic Biol Med., 45(4), 475481. doi: 10.1016/j.freeradbiomed.2008.04.041. 
Al-Azemi, M., Omu, F.E., Kehinde, E.O., Anim, J.T., Oriowo, M.A., \& Omu, A.E. (2010). Lithium protects against toxic effects of cadmium in the rat testes. J. Assist. Reprod. Genet, 27(8), 469-476. doi: 10.1007/s10815-010-9426-3.

Antonio, M.T., Benito, M.J., Leret, M.L., \& Corpas, I. (1998). Gestation administration of cadmium alters the neurotransmitter levels in newborn rat brains. J Appl Toxicol., 18(2), 83-88. https://www.ncbi.nlm.nih.gov/pubmed/9570689.

Pavan Kumar, G., \& Prasad, M.N.V. (2004). CadmiumInducible Proteins in Ceratophyllum demersum L. (a Fresh Water Macrophyte): Toxicity Bioassays and Relevance to Cadmium Detoxification. Bulletin of Environmental Contamination and Toxicology, 73(1), 174-181. doi: 10.1007/s00128-004-0410-4.

El-Shahat, A.E., Gabr, A., Meki, A.R., \& Mehana, E.S. (2009). Altered testicular morphology and oxidative stress induced by cadmium in experimental rats and protective effect of simultaneous green tea extract. Int. J. Morphol., 27(3), 757-764. doi: 10.4067/S071795022009000300020.

Ali, M.M., Murthy, R.C., \& Chandra, S.V. (1986). Developmental and longterm neurobehavioral toxicity of low-level in utero $\mathrm{Cd}$ exposure in rats. Neurobehavioral Toxicology and Teratology, 8(5), 463-468. https://www.ncbi.nlm.nih.gov/pubmed/3785508.

El-Refaiy, A.I., \& Eissa, F.I. (2012). Protective effects of ascorbic acid and zinc against cadmium-induced histopathological, histochemical and cytogenetic changes in rats. Comunicata Scientiae, 3(3), 162-180. https://www.comunicatascientiae.com.br/comunicata/a rticle/view/186/136.

Salvatori, F., Talassi, CB, Salzgeber, S.A., Sipinosa, H.S., \& Bernardi, M.M. (2004). Embryotoxic and long-term effects of cadmium exposure during embryogenesis in rats. Neurotoxicology and Teratology, 26(5), 673680. doi: 10.1016/j.ntt.2004.05.001.
Peng, L., Wang, X., Huo, X., Xu, X., Lin, K., Zhang, J., Huang, Y., \& Wu, K. (2015). Blood cadmium burden and the risk of nasopharyngeal carcinoma: a casecontrol study in Chinese Chaoshan population. Environmental Science and Pollution Research, 22(16), 12323-12331. doi: 10.1007/s11356-015-4533-4.

Gutyj, B.V. (2015). The activity of antioxidant protecting of the bulls for acute cadmium toxicosis. Scientific Messenger of LNU of Veterinary Medicine and Biotechnologies, 17(1), 31-36. Retrieved from https://nvlvet.com.ua/index.php/journal/article/view/2 14.

Vlizlo, V.V. (2012). Laboratorni metody doslidzhen u biolohiyi, tvarynnytstvi ta veterynarniy medytsyni [Laboratory methods of investigation in biology, stock-breeding and veterinary]. Spolom, Lviv (in Ukrainian)

Gutyj, B., Hufriy, D., Binkevych, V., Vischur, V., Binkevych, O., \& Kurlyak, I. (2015). The changes of biochemical and morphological indices of rats' blood under chronic cadmium toxicosis. Scientific Messenger of LNU of Veterinary Medicine and Biotechnologies, 17(3), 120-123. Retrieved from https://nvlvet.com.ua/index.php/journal/article/view/5 31 .

Gutyj, B.V., Binkevych, V., \& Binkevych, O. (2016). Hematological changes of rats after cadmium toxicosis. Scientific Messenger of LNU of Veterinary Medicine and Biotechnologies, 18(1), 165-167. Retrieved from https://nvlvet.com.ua/index.php/ journal/article/view/110.

Khariv, M., Gutyj, B., Butsyak, V., \& Khariv, I. (2016). Hematological indices of rat organisms under conditions of oxidative stress and liposomal preparation action. Biological Bulletin of Bogdan Chmelnitskiy Melitopol State Pedagogical University. 6 (1), 276-289. doi: $10.15421 / 201615$ 